\title{
Modeling Dose-Response Relationships in Biological Control: Partitioning Host Responses to the Pathogen and Biocontrol Agent
}

\author{
Kevin P. Smith, Jo Handelsman, and Robert M. Goodman
}

University of Wisconsin, Department of Plant Pathology, 1630 Linden Drive, Madison 53706.

Accepted for publication 31 March 1997.

\section{ABSTRACT}

Smith, K. P., Handelsman, J., and Goodman R. M. 1997. Modeling doseresponse relationships in biological control: Partitioning host responses to the pathogen and biocontrol agent. Phytopathology 87:720-729.

Breeding plants to improve the effectiveness of biocontrol agents is a promising approach to enhance disease suppression by microorganisms. Differences in biocontrol efficacy among cultivars suggest there is genetic variation for this trait within crop germplasm. The ability to quantify host differences in support of biological control is influenced by variation in host response to the pathogen and the dose of pathogen and biocontrol agent applied to the host. To assess the contribution of each of these factors to successful biocontrol interactions, we measured disease over a range of pathogen (Pythium) and biocontrol agent (Bacillus cereus UW85) inoculum doses. We fit dose-response models to these data and used model parameter estimates to quantify host differences in response to the pathogen and biocontrol agent. We first inoculated eight plant species separately with three species of Pythium and evaluated three doseresponse models for their ability to describe the disease response to pathogen inoculum level. All three models fit well to at least some of the host-pathogen combinations; the hyperbolic saturation model provided the best overall fit. To quantify the host contribution to biological control, we next evaluated these models with data from a tomato assay, using six inbred tomato lines, $P$. torulosum, and UW85. The lowest dose of pathogen applied revealed the greatest differences in seedling mortality among the inbred lines, ranging from 40 to $80 \%$. The negative exponential (NE) pathogen model gave the best fit to these pathogen data, and these differences corresponded to model parameter values, which quantify pathogen efficiency, of 0.023 and 0.091 . At a high pathogen dose, we detected the greatest differences in biocontrol efficacy among the inbred lines, ranging from no effect to a $68 \%$ reduction in mortality. The NE pathogen model with a NE biocontrol component, the NE/NE biocontrol model, gave the best fit to these biocontrol data, and these reductions corresponded to model parameter values, which quantify biocontrol efficiency, of 0.00 and 0.038 , respectively. There was no correlation between the host response to the pathogen and biocontrol agent for these inbred lines. This work demonstrates the utility of epidemiological modeling approaches for the study of biological control and lays the groundwork to employ manipulation of host genetics to improve biocontrol efficacy.

Additional keywords: damping-off.
Plant breeders have exploited host variation for disease resistance since the beginning of the 20th century but only recently has attention been focused on the potential of exploiting host variation for response to beneficial organisms or biocontrol agents $(3,8,31)$. Several workers have observed variation among crop species in response to introduced beneficial microbes $(2,5,24,35)$. Similarly, cultivars of a single crop treated with beneficial microbes can differ in plant-growth response $(1,4,17)$, degree of root colonization (10), and ability to support biological control $(9,14,20,31,32)$. If these differences among cultivars for support of biological control are due to heritable traits, then it should be possible to exploit this genetic variation to improve disease management.

Although phenotypic differences for support of biological control have been reported, methods for quantifying such a trait and partitioning it from host response to the pathogen have not been developed. Because measurements of biological control are made in the presence of a pathogen, selection for biocontrol supportiveness in a breeding program must take into account differences in host response to the pathogen.

The ability to quantify cultivar differences in response to pathogens is influenced by the concentration of the pathogen inoculum. Intuitively, pathogen inoculum doses that result in close to $100 \%$ mortality will obscure potential cultivar differences that would be apparent at lower doses. Likewise, the ability to quantify biologi-

Corresponding author: R. M. Goodman

E-mail address: RGoodman@facstaff.wisc.edu

Publication no. P-1997-0424-01R

(C) 1997 The American Phytopathological Society cal control is affected by the inoculum dose of the pathogen, and it is often necessary to use high pathogen inoculum doses to measure biocontrol efficacy $(11,18)$. Leeman et al. (19) found that various inoculum densities of Fusarium were needed to detect biological control on radish cultivars differing in their level of wilt resistance. Because measurement of host support of biological control requires measurement of both biocontrol efficacy and disease resistance, it is necessary to integrate information over a range of pathogen and biocontrol agent inoculum concentrations to measure both of these traits accurately.

Recently, epidemiological models of dose-response relationships in biological control have been used to describe the relationships among host, pathogen, and biocontrol agent over a range of inoculum concentrations $(12,23,27)$. These biocontrol models are extensions of disease models initially described by Van der Plank (34). Johnson (12) extended the concept of host-pathogen models of disease to include host response to a biocontrol agent and proposed a model to predict disease as a function of the density of the pathogen and biocontrol agent. Montesinos and Bonaterra (23) developed a methodology for evaluating this and other models and used these models to estimate epidemiological parameters in several biocontrol systems. We propose that parameter values from such models can be used to quantify the host contribution to biological control in a way that will partition this trait from host response to the pathogen.

Here we report the development of a method to quantify host support of biological control using suppression of Pythium damping-off by Bacillus cereus UW85. We evaluated three pathogen dose-response models for goodness-of-fit to disease data on a range of plant hosts with three species of Pythium. To quantify 
biological control, we evaluated biocontrol dose-response models based on the three pathogen dose-response models for goodnessof-fit to data from tomato biocontrol assays, and we used parameter values estimated by nonlinear regression to quantify biocontrol supportiveness. Disease resulted in every pathogen-host combination evaluated in this study; however, in many cases the level of disease was different. When we observed differences among hosts in their response to the pathogen, we interpreted these to be due to host differences in resistance to the pathogen. Likewise, when we observed differences among hosts in their response to the biocontrol agent, we interpreted these to be due to host differences in support of biological control.

\section{MATERIALS AND METHODS}

Pythium inoculum preparation. Pythium isolate A25a was baited from field soil from Marshfield, WI, with the root of an alfalfa (cv. Agate) seedling; isolate L38 was obtained from turfgrass in North Carolina; and isolate E17 was isolated from the roots of an alfalfa plant grown at Hancock, WI. A25a, L38, and E17 were identified as $P$. torulosum Coker \& F. Patterson, $P$. aphanidermatum (Edson) Fitzp., and P. aristosporum Vanterpool, respectively, by D. J. S. Barr, Agriculture Canada, Ottawa. Isolates were maintained on V8-juice agar plates (6) and transferred every 2 weeks. Isolates were transferred periodically to medium amended with either streptomycin $(100 \mu \mathrm{g} / \mathrm{ml})$, chlortetracycline $(50 \mu \mathrm{g} / \mathrm{ml})$, or rifampicin $(50 \mu \mathrm{g} / \mathrm{ml})$ to control persistent bacterial contamination of the cultures.

Zoospores were prepared and enumerated by methods previously described (29). The three isolates differed in production of zoospores. A25a produced $10^{5}$ to $10^{6}$ zoospores per $\mathrm{ml} 4 \mathrm{~h}$ after the final water change. Isolates L38 and E17 typically produced $10^{3}$ to $5 \times 10^{4}$ zoospores per $\mathrm{ml} 4$ to $8 \mathrm{~h}$ after the final water change. Occasionally, isolate E17 had to be incubated longer, and the plates had to be rinsed several times to obtain zoospores. Zoospore inoculum was diluted to the desired concentration with sterile distilled water.

Pythium dose-response experiments. To examine the effect of Pythium dose on seedling disease, we evaluated the response of eight plant species to inoculation with three Pythium species in growth-chamber assays at $24^{\circ} \mathrm{C}$ and $40 \%$ relative humidity, with $12 \mathrm{~h}$ of continuous light $\left(415 \mu \mathrm{E} \mathrm{m} \mathrm{m}^{-2} \mathrm{~s}^{-1}\right.$ provided by fluorescent bulbs) per 24-h period. Seeds were surface-disinfested by sequential soaking for $30 \mathrm{~s}$ each in ethanol $(70 \%)$, sodium hypochlorite (1\%), and distilled water and dried in a laminar flow hood. For each experimental unit, we filled a 112-ml waxed cup, which had four holes punched in the bottom for drainage, with $60 \mathrm{~cm}^{3}$ of autoclaved medium-grade vermiculite (Strong-Lite, Pine Bluff, AR), planted five seeds in the cup, and placed it in a $28 \times 56-\mathrm{cm}$ plastic tray (Hummert Int., Earth City, MO). We prepared four 10fold dilutions of the zoospore suspension of each Pythium species for use as inoculum. We applied the zoospore suspension as a drench. Inoculum concentration is expressed as the number of zoospores applied divided by the number of seeds planted. From the results of preliminary experiments (data not shown), we knew that isolates E17, L38, and A25a differed in the concentration of zoospores necessary to cause a given level of disease. To account for these differences, we staggered the highest concentration applied for the Pythium isolates such that the highest dose for E-17, L38, and A25a was $10^{3}, 10^{4}$, and $10^{5}$ zoospores per seed, respectively.

The experimental design was a randomized complete block arranged in a split plot with four replications in time. The 13 main plots (plastic trays) were the 3 Pythium isolates, each at 4 zoospore concentrations and 1 distilled water control. Three cultivars of each of the eight plant species (Table 1) comprised the twentyfour subplots (cups). After planting, we added 4 liters of water to each tray, pipetted $1 \mathrm{ml}$ of zoospores or water into each cup, and covered the trays with clear plastic domes (Hummert). During the experiment, we added water to the trays as necessary to maintain the water level in the tray that was present at the beginning of the experiment. We assessed the incidence of seedling damping-off disease by counting the number of plants that emerged in each cup.

On the twelfth day after planting, we cut root segments (1 to $2 \mathrm{~cm}$ ) from two arbitrarily selected seedlings from each cup, soaked them in sodium hypochlorite $(1 \%)$ for $30 \mathrm{~s}$, rinsed them in sterile distilled water, and placed them on water agar (WA) plates held at $24^{\circ} \mathrm{C}$. After 2 days, we scored the roots for the presence of Pythium-like mycelial growth. The leading edge of any Pythiumlike colonies that appeared was transferred to V8-juice medium, cultured for 2 days, and compared microscopically to the inoculum isolate to confirm the pathogen's identity. All three isolates exhibited distinct growth phenotypes on both WA and V8-juice medium, and we, therefore, could distinguish them confidently by visual inspection, allowing us to detect any possible cross-contamination.

Pythium and UW85 dose-response experiment. We examined the effect of both $P$. torulosum and UW85 on tomato seedling emergence in growth-chamber assays. Experiments were conducted as described above, except we planted seeds in 72-cell inserts (Hummert) that fit inside the planting trays rather than in waxed cups.

Tomato seeds. We chose six tomato lines from a $\mathrm{BC}_{1} \mathrm{~S}_{4}$ population produced from a cross between Lycopersicon esculentum L. cv. UC82B and L. pennellii L. accession LA716, with UC82B as the recurrent parent. We obtained the $\mathrm{BC}_{1} \mathrm{~S}_{2}$ generation of this population from $\mathrm{J}$. Nienhuis and produced the $\mathrm{BC}_{1} \mathrm{~S}_{3}$ and $\mathrm{BC}_{1} \mathrm{~S}_{4}$ lines in the field by single-seed descent. We bulked the fruit from individual plants, cut each fruit transversely, and scraped the seeds and gel from the locules into glass beakers. We added $6 \mathrm{M} \mathrm{HCl}$, $8 \mathrm{ml}$ per $100 \mathrm{ml}$ of seed and gel, and let the mixture sit for no longer than $30 \mathrm{~min}$. We strained the seeds though a colander, put them in a beaker, soaked them in $10 \%$ trisodium phosphate for 30 min, rinsed them with water, and air-dried them on paper towels.

UW85 seed treatment. We evaluated four doses of $B$. cereus UW85 for its potential to suppress disease caused by $P$. torulosum

TABLE 1. Plant germplasm used in pathogenicity experiments

\begin{tabular}{|c|c|c|}
\hline Plant & Cultivar or ecotype & Source \\
\hline Allium sativa $\mathrm{L}$. & $\begin{array}{l}\text { Brigham Yellow } \\
\text { Gold } \\
\text { White Creole } \\
\text { Yellow Bermuda }\end{array}$ & $\begin{array}{l}\text { USDA Vegetable Genetics, UWM } \\
\text { USDA Vegetable Genetics, UWM } \\
\text { USDA Vegetable Genetics, UWM }\end{array}$ \\
\hline Arabidopsis thaliana $\mathrm{L}$. & $\begin{array}{l}\text { Columbia } \\
\text { Landsberg erecta } \\
\text { Weiningen }\end{array}$ & $\begin{array}{l}\text { Lehle Seeds, Tucson, AZ } \\
\text { Lehle Seeds, Tucson, AZ } \\
\text { Lehle Seeds, Tucson, AZ }\end{array}$ \\
\hline Cucumis sativa $\mathrm{L}$. & $\begin{array}{l}\text { GY14 } \\
\text { Little Leaf } \\
\text { Marketmore }\end{array}$ & $\begin{array}{l}\text { USDA Vegetable Genetics, UWM } \\
\text { J. W. Jung Seed Co., Randolph, WI } \\
\text { J. W. Jung Seed Co., Randolph, WI }\end{array}$ \\
\hline Lolium perenne L. & $\begin{array}{l}\text { All Star } \\
\text { Prelude II } \\
\text { Yorktown }\end{array}$ & $\begin{array}{l}\text { F. Rossi, UWM } \\
\text { F. Rossi, UWM } \\
\text { F. Rossi, UWM }\end{array}$ \\
\hline $\begin{array}{l}\text { Lycopersicon esculentun } \\
\text { Mill. }\end{array}$ & $\begin{array}{l}\text { Bonny Best } \\
\text { Chico III } \\
\text { Wisconsin-55 }\end{array}$ & $\begin{array}{l}\text { Stokes Seed, Buffalo, NY } \\
\text { J. W. Jung Seed Co., Randolph, WI } \\
\text { J. W. Jung Seed Co., Randolph, WI }\end{array}$ \\
\hline Medicago sativa $\mathrm{L}$. & $\begin{array}{l}\text { Iroquois } \\
\text { Magnum III } \\
\text { Vernal }\end{array}$ & $\begin{array}{l}\text { T. Bingham, UWM } \\
\text { T. Bingham, UWM } \\
\text { T. Bingham, UWM }\end{array}$ \\
\hline Nicotiana tabacum $\mathrm{L}$. & $\begin{array}{l}\text { Havana } 142 \\
\text { Havana } 608 \\
\text { Xanthi nc }\end{array}$ & $\begin{array}{l}\text { M. Drilias, UWM } \\
\text { M. Drilias, UWM } \\
\text { Our laboratory stocks }\end{array}$ \\
\hline Zea mays $\mathrm{L}$. & $\begin{array}{l}\text { B73 } \\
\text { H-99 } \\
\text { Mo-17 }\end{array}$ & $\begin{array}{l}\text { J. Coors, UWM } \\
\text { J. Coors, UWM } \\
\text { J. Coors, UWM }\end{array}$ \\
\hline
\end{tabular}

${ }^{\text {a }} \mathrm{UWM}=$ University of Wisconsin, Madison. 
on six tomato lines. We grew UW85 in $1 / 2$-strength tryptic soy broth (Difco Laboratories, Detroit) for 4 days at $29^{\circ} \mathrm{C}$ to obtain fully sporulated cultures as described previously (28). To generate a range of UW85 doses, we diluted bacterial cultures with sterile water in 1:1, 1:3, and 1:7 (culture/sterile distilled water) ratios. We counted the seeds to be treated into 200- $\mu$ l pipette tips (Research Products International Corp., Mount Prospect, IL) arranged in a pipette-tip box modified to allow us to create a vacuum inside the box. We added the bacterial suspension $(100 \mu \mathrm{l})$ to the seeds in each tip and 3 min later applied a vacuum to remove the excess culture and dry the seeds. This system facilitated the treatment of different tomato lines with several concentrations of UW85 and minimized the time that seeds remained wet. We enumerated bacterial cells that adhered to the seeds by selecting one seed of each tomato line at random from each replicate, sonicating (Branson Ultrasonics Corporation, Danbury, CT) for $30 \mathrm{~s}$ in sterile water, and dilution plating on $1 / 10$-strength tryptic soy agar (Difco) plates. We incubated dilution plates at $24^{\circ} \mathrm{C}$ for 2 days and counted the CFU.

We planted seeds coated with various concentrations of UW85, 10 seeds per cell, in plastic planting trays we had filled previously with autoclaved vermiculite $\left(40 \mathrm{~cm}^{3}\right.$ per cell). After planting, we added enough vermiculite to cover the seeds and added 4 liters of distilled water or zoospore suspension to each flat. We replaced the volume of water lost by evaporation every $12 \mathrm{~h}$ to maintain a constant level throughout the experiment. The experiment design was a randomized complete block arranged in a split plot. The five main plots were $P$. torulosum inoculated at $0,25,50,100$, and 200 zoospores per seed. The subplots were the six tomato lines untreated or treated with four concentrations of UW85. We evaluated untreated seeds at all pathogen doses, 1:1, 1:3, and 1:7 doses of UW85 at a 100 zoospores per seed dose, and undiluted, 1:1, and 1:3 doses of UW85 at a 200 zoospores per seed dose. Each of the 24 subplot treatments were replicated three times within a main plot, and the main plots were replicated twice in time. We counted emerged healthy seedlings daily until the experiment ended 12 days after planting. We selected two lines that differed in support of biological control based on the results of the experiment described above and, with the remaining seed, evaluated them in two experiments treated with undiluted UW85 culture and inoculated with $P$. torulosum (50 zoospores per seed).

Data analysis. We converted emergence data to proportion seedling mortality, using as the denominator the emergence in the control that was not treated with Pythium or UW85 and subtracting this fraction from 1 . Disease and biocontrol models were fit to these data, using the Statistical Analysis System nonlinear regression procedure NLIN with the Gauss-Newton method of iteration (SAS Institute, Cary, NC). Because these data can be expressed categorically, we chose to assess goodness-of-fit by the chi-square test to

TABLE 2. Pathogen models expressing seedling mortality $(Y)$ as a function of the inoculum dose of the pathogen $(x)$, measured as zoospores per seed ${ }^{\mathrm{a}}$

\begin{tabular}{|c|c|c|c|c|}
\hline \multirow[b]{2}{*}{ Model name } & \multirow[b]{2}{*}{ Equation } & \multicolumn{3}{|c|}{ Model parameters } \\
\hline & & Asymptote & Rate & $\mathrm{ED}_{50}^{\mathrm{b}}$ \\
\hline Negative exponential $^{c}$ & $Y=L[1-\exp (-k x)]$ & $L$ & $k$ & \\
\hline Hyperbolic saturation $^{\mathrm{d}}$ & $Y=Y_{\max }\left(\frac{x}{x+K_{x}}\right)$ & $Y_{\max }$ & & $K_{x}$ \\
\hline $\begin{array}{l}\text { Logistic cumulative } \\
\text { probability }^{\mathrm{e}}\end{array}$ & $Y=\frac{1}{1+\exp \left[\frac{\pi(\mu-x)}{\sqrt{3} \cdot \delta}\right.}$ & & $\delta$ & $\mu$ \\
\hline
\end{tabular}

${ }^{a}$ Each of these models uses two parameters to relate disease to the inoculum dose of the pathogen.

b $50 \%$ effective dose.

${ }^{\mathrm{c}}$ From equation 2 in reference 12.

d From equation 2 in reference 23.

${ }^{\mathrm{e}}$ Closed form of the cumulative logistic distribution curve. evaluate the null hypothesis (model = observed). We calculated the observed and predicted number of dead seedlings by multiplying mortality by the number of seedlings emerged in the uninoculated control. The confidence intervals for parameter estimates and asymptotic correlation coefficients were calculated by NLIN.

Models for host response to pathogen and biocontrol agent. We generated pathogen and biocontrol models using three nonlinear functions: negative exponential (NE), hyperbolic saturation (HS), and logistic (LG). In the pathogen models, each of these two-parameter functions relates mortality to pathogen inoculum dose $(x)$ (Table 2). Biocontrol functions relate the proportion of ineffective pathogen inoculum $\left(x_{i} / x\right)$ to a two-parameter function of biocontrol agent inoculum dose (z) (Table 3). The biocontrol models consist of a pathogen model in which the pathogen inoculum dose is multiplied by one of the biocontrol functions. All of the parameters in these models define either an asymptote, an effective dose $\left(\mathrm{ED}_{50}\right)$, or a rate of change in disease. Asymptote parameters, expressed as a proportion, correspond to the maximum potential for disease (in the pathogen model) or disease suppression (in the biocontrol model). The asymptote in the LG function is defined as 1 , whereas in the NE and HS functions it is defined by a parameter. For all three functions, when the inoculum dose is $0, Y$ or $x_{i} / x$ is defined as 0 , thus the models predict when there is no pathogen there is no disease and, likewise, when there is no biocontrol agent there is no reduction in disease. $\mathrm{ED}_{50}$ parameters position the curve by defining the dose at which disease is half of the maximum. In the pathogen model, the $\mathrm{ED}_{50}$ is the number of zoospores per seed that results in $50 \%$ of the maximum level of mortality, and in the biocontrol model, the $\mathrm{ED}_{50}$ is the CFU per seed of UW85 that results in 50\% of the maximum level of reduction in mortality. Rate parameters determine how rapidly disease changes with respect to increasing inoculum dose of either the pathogen or the biocontrol agent. Rate and $\mathrm{ED}_{50}$ parameters can be interpreted as measurements of pathogen or biocontrol agent efficiency.

\section{RESULTS}

Evaluating disease on diverse plant hosts. Mortality increased with increasing inoculum dose for all three Pythium isolates on the

TABLE 3. Biocontrol functions expressing the proportion of pathogen inoculum rendered ineffective $\left(x_{i} / x\right)$ as a function of the inoculum dose of the biocontrol agent $(z)^{\mathrm{a}}$

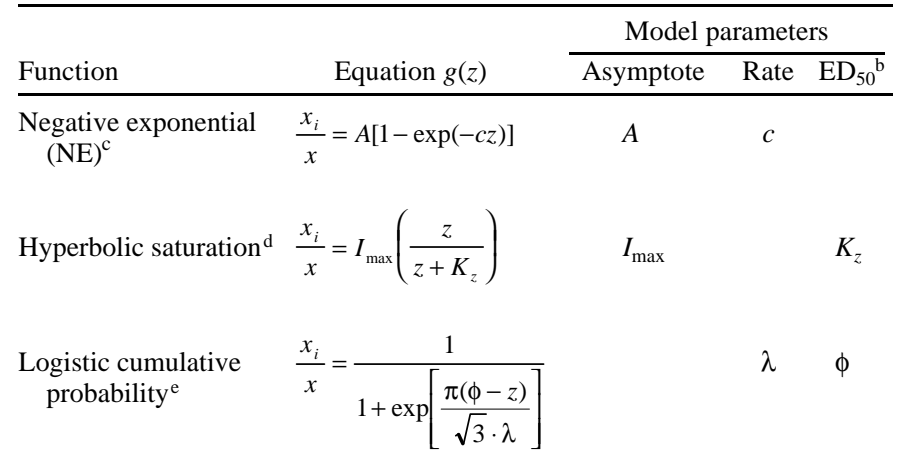

\footnotetext{
a Each biocontrol model is based on one of the three pathogen models (Table 2), in which the inoculum dose of the pathogen $(x)$ is multiplied by the biocontrol function $\left(x_{i} / x\right)$. For example, the NE/NE biocontrol model is the NE pathogen model, where $x$ is multiplied by the $\mathrm{NE}$ biocontrol function yielding the equation $Y=L[1-\exp (-k x\{A[1-\exp (-c z)]\})]$. Each biocontrol model uses two parameters to relate disease to inoculum dose of the pathogen and two parameters to relate the proportion of the effective pathogen dose to the dose of the biocontrol agent.

b $50 \%$ effective dose.

c From equation 4 in reference 23.

${ }^{\mathrm{d}}$ From equation 7 in reference 23

e Closed form of the cumulative logistic distribution curve.
} 
eight plant species; however, there were differences in the magnitude of the response of a host to the pathogens among the plant species. Analysis of variance conducted for each of the main-plot treatments (Pythium isolate at a single inoculum dose) indicated that the cultivar effect on seedling mortality was significant for only 1 of the 12 main-plot treatments. The plant species effect, on the other hand, was significant for 9 of the 12 main-plot treatments. Based on these results, we pooled the cultivar data for each plant species, and further analysis was based on the mean of the three cultivars for each plant species.

We quantified the host responses to the three Pythium isolates, using parameter values from dose-response models. Based on the $P$ value for the chi-square test, the HS and NE models gave the best overall fit for the host response to the pathogen, whereas the LG model fit well for less than half of the pathogen-host combinations (Table 4). In general, all three models gave a poorer fit to the data for $P$. aristosporum than for either $P$. aphanidermatum or $P$. torulosum. In some cases, none of the three models fit well for a particular host-pathogen combination, e.g., Arabidopsis and $P$. aristosporum (Table 4). In this case, the poor fit likely resulted from the lack of data at the asymptote portion of the curve, which would be inadequate to estimate $L$ or $Y_{\max }$. Too few points in the steepest portion of the curve occurred with the combination of onion and $P$. aristosporum, which resulted in a reasonable fit to the data but very large confidence intervals for $k$ (data not shown). In this case, the steepest portion of the curve occurs between inoculum doses of 0 and 1 zoospore per seed and is not shown on the graph.

Where the models gave reasonable fits to the data, the parameter values confirmed the expected differences in host response to the Pythium isolates, indicating that $P$. aristosporum was most aggressive (requiring the fewest pathogen propagules to produce disease) and $P$. torulosum was the least aggressive overall (Table 4). Among the host-pathogen combinations that yielded good fits, there were some clear differences in host response to the patho- gen. In general, corn and Arabidopsis showed the least disease caused by the Pythium isolates tested (Fig. 1 and Table 4). The relative disease severity among the plant species differed among the three Pythium isolates. Cucumber is one such example; based on $K_{x}$ values from the HS model, cucumber appears to be one of the most resistant hosts to $P$. torulosum but is relatively less resistant to $P$. aphanidermatum.

Quantifying host resistance to the pathogen. We selected the tomato- $P$. torulosum system for further study based on good fits for all of the pathogen models (Table 4), ease of manipulation in this bioassay, and potential for future study of host genetics. The six tomato lines studied differed in their level of resistance to the pathogen. The largest differences among lines were apparent at the lowest pathogen dose ( 25 zoospores per seed), with mortality ranging from 40 to $80 \%$ (Fig. 2).

We quantified these differences in terms of model parameter values by fitting the three pathogen models (Table 2) to mortality data from the pathogen dose-response assay. Because for the NE and HS models the asymptote model parameters $L$ and $Y_{\max }$ were very close to 1.0 , we also evaluated one-parameter versions of these models by setting $L$ and $Y_{\max }=1$. In addition, other experiments in the tomato system resulted in $100 \%$ mortality when high pathogen doses were used (K. P. Smith, J. Handelsman, and R. M. Goodman, unpublished data), suggesting that 1 is an appropriate value for these asymptote parameters. Among the five models, the NE model gave the best overall fit to the data (Table 5 and Fig. 2). Poorer fits were associated with tomato lines in which there were insufficient observations at informative points of the curve, resulting in larger confidence intervals for parameter estimates. For example, NIJ 8 had no data points in the steepest portion of the doseresponse curve, had the poorest fit for any of the models, and had the largest confidence intervals for the rate parameters, $k$ and $\delta$, for the NE and LG models, respectively (Table 5).

One concern when fitting two-parameter models is the possibility of over-parameterization, which is indicated by correlation

TABLE 4. Parameter values and goodness-of-fit for three pathogen dose-response models evaluated for eight plant species and three strains of Pythium

\begin{tabular}{|c|c|c|c|c|c|c|c|c|c|c|}
\hline \multirow[b]{2}{*}{ Pythium sp. } & \multirow[b]{2}{*}{ Host } & \multicolumn{3}{|c|}{ Negative exponential model } & \multicolumn{3}{|c|}{ Hyperbolic saturation model } & \multicolumn{3}{|c|}{ Logistic cumulative probability mode } \\
\hline & & $L$ & $k$ & $P^{\mathrm{a}}$ & $Y_{\max }$ & $K_{x}$ & $P$ & $v$ & $\delta$ & $P$ \\
\hline \multirow[t]{9}{*}{ P. torulosum } & Alfalfa & 0.65 & 0.0104 & 0.90 & 0.66 & 54.5 & 0.87 & 653.0 & 825.0 & 0.00 \\
\hline & Arabidopsis & 0.87 & 0.0020 & 0.72 & 0.90 & 286.7 & 0.97 & 689.9 & 559.5 & 0.16 \\
\hline & Corn & 0.68 & 0.0006 & 0.00 & 0.72 & $1,299.7$ & 0.05 & $1,490.3$ & 998.0 & 0.00 \\
\hline & Cucumber & 0.94 & 0.0025 & 0.78 & 0.98 & 246.4 & 0.98 & 563.5 & 509.8 & 0.25 \\
\hline & Onion & 0.86 & 0.0164 & 0.73 & 0.87 & 25.5 & 0.74 & 93.9 & 13.6 & 0.19 \\
\hline & Ryegrass & 0.62 & 0.0118 & 0.93 & 0.63 & 49.3 & 0.97 & 800.0 & $1,043.1$ & 0.00 \\
\hline & Tobacco & 0.92 & 0.0116 & 0.72 & 0.94 & 53.5 & 0.84 & 96.0 & 13.9 & 0.47 \\
\hline & Tomato & 0.98 & 0.0095 & 1.00 & 1.00 & 65.7 & 1.00 & 97.1 & 12.9 & 0.99 \\
\hline & Overall $^{\mathrm{b}}$ & & & 0.94 & & & 1.00 & & & $<0.01$ \\
\hline \multirow[t]{9}{*}{ P. aristosporum } & Alfalfa & 0.63 & 0.1891 & 0.38 & 0.65 & 3.1 & 0.85 & 460.3 & 952.6 & 0.00 \\
\hline & Arabidopsis & 0.51 & 0.0195 & 0.00 & 0.55 & 43.0 & 0.00 & $1,055.7$ & 925.2 & 0.00 \\
\hline & Corn & 0.44 & 0.2165 & 0.77 & 0.45 & 2.9 & 0.43 & $1,526.3$ & $2,301.3$ & 0.00 \\
\hline & Cucumber & 0.68 & 0.0068 & 0.00 & 0.76 & 118.5 & 0.00 & 760.2 & 523.9 & 0.00 \\
\hline & Onion & 0.72 & 1.9459 & 0.99 & 0.72 & 0.2 & 1.00 & 14.6 & 1536.5 & 0.01 \\
\hline & Ryegrass & 0.69 & 0.1232 & 0.50 & 0.73 & 6.1 & 0.37 & 77.0 & 89.3 & 0.00 \\
\hline & Tobacco & 0.60 & 0.0822 & 0.72 & 0.64 & 10.5 & 0.84 & 589.9 & 827.7 & 0.47 \\
\hline & Tomato & 0.52 & 0.1154 & 1.00 & 0.55 & 7.2 & 1.00 & 751.1 & 946.9 & 0.99 \\
\hline & Overall & & & $<0.01$ & & & $<0.01$ & & & $<0.01$ \\
\hline \multirow[t]{9}{*}{ P. aphanidermatum } & Alfalfa & 0.92 & 0.0376 & 1.00 & 0.96 & 18.5 & 0.80 & 10.7 & 1.5 & 0.73 \\
\hline & Arabidopsis & 0.82 & 0.0076 & 0.28 & 0.85 & 90.2 & 0.76 & 111.9 & 71.9 & 0.11 \\
\hline & Corn & 0.60 & 0.0724 & 0.60 & 0.63 & 12.3 & 0.82 & 581.7 & 969.3 & 0.00 \\
\hline & Cucumber & 0.99 & 0.0550 & 1.00 & 1.03 & 13.1 & 0.94 & 10.2 & 1.3 & 1.00 \\
\hline & Onion & 0.81 & 0.1658 & 0.20 & 0.81 & 2.0 & 0.17 & 9.5 & 1.5 & 0.02 \\
\hline & Ryegrass & 0.70 & 0.0202 & 0.25 & 0.72 & 31.1 & 0.06 & 85.3 & 45.3 & 0.00 \\
\hline & Tobacco & 0.97 & 0.0095 & 0.00 & 0.98 & 55.8 & 0.07 & 89.6 & 84.5 & 0.12 \\
\hline & Tomato & 0.96 & 0.0733 & 0.90 & 1.00 & 10.2 & 1.00 & 10.0 & 1.4 & 0.83 \\
\hline & Overall & & & 0.15 & & & 0.84 & & & $<0.01$ \\
\hline
\end{tabular}

a Probability of the chi-square test (model = observed).

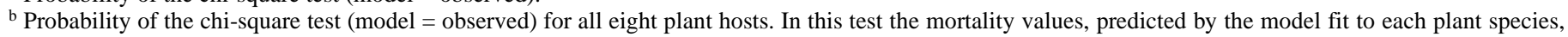
are compared with the observed values to assess how well the model predicted disease by the pathogen across the eight plant species. 
between parameters. Asymptotic correlation coefficients for the six inbred lines ranged from -0.56 to -0.76 for the NE model and from 0.82 to 0.90 for the HS model, indicating that this may be a problem for the HS model in particular. For all of the tomato lines, the one-parameter versions of the NE and HS models had slightly poorer fits but also had smaller confidence intervals associated with the parameter estimate, allowing better discrimination of differences among the tomato lines. Using either the value for $k$ or $K_{x}$ from the NE or HS models, respectively, to quantify the response to the pathogen, NIJ 66 was the most resistant, whereas NIJ 8 was the least resistant among the six lines (Table 5).

Quantifying host contribution to biological control. The six tomato lines also differed in their response to the biocontrol agent. These differences were most apparent when seeds were coated with a 1:3 (UW85/sterile water) bacterial suspension and inoculated with Pythium at 100 zoospores per seed. At these doses, there
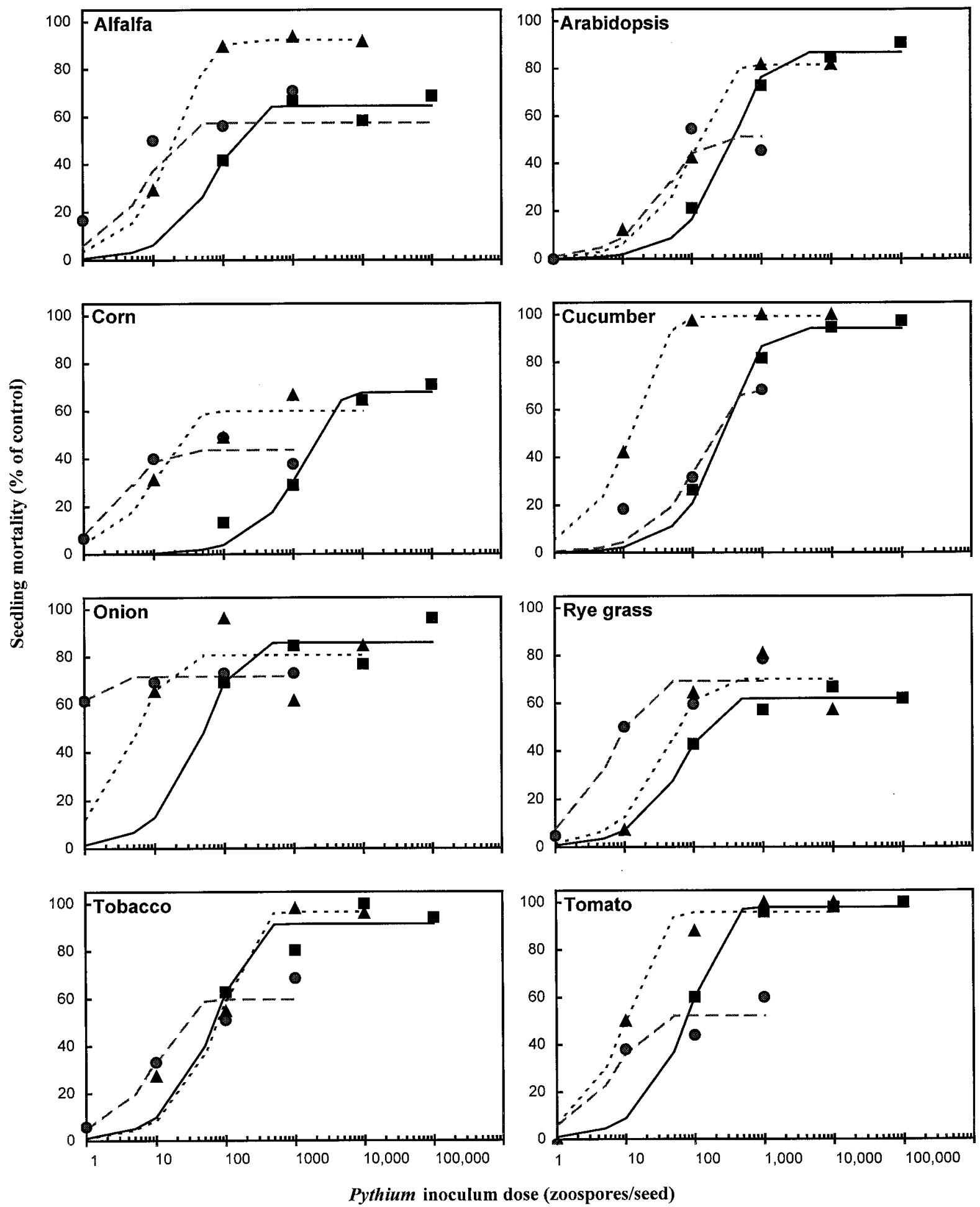

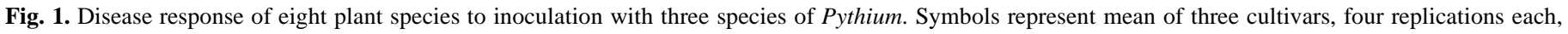

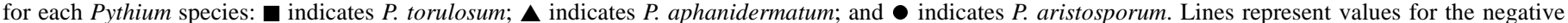

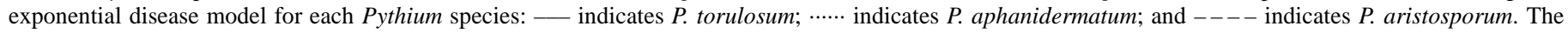

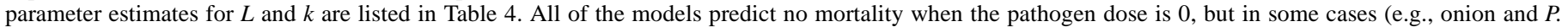
aristosporum), the model intercepts the $\mathrm{y}$-axis drawn at inoculum dose $=1$ zoospore per seed. 
was no reduction in mortality for NIJ 66 and a $68 \%$ reduction in mortality for NIJ 87 (Fig. 3).

To quantify differences among host genotypes for support of biological control over the entire range of inoculum doses, we evaluated three biocontrol models based on the NE pathogen doseresponse model. In each of these models, the effective pathogen inoculum in the pathogen dose-response model is reduced by some function of the dose of the biocontrol agent. For example, a model based on the NE dose-response to the pathogen (Table 2) and the HS dose response of the pathogen to the biocontrol agent (Table 3) would be called NE/HS. We fit each of these models to seedling mortality of tomato lines treated with different doses of UW85 and inoculated with $P$. torulosum.

The dose of UW85 was measured as CFU per seed resulting from the application of various concentrations of bacterial suspension. For all tomato lines, there was a linear relationship between the amount of UW85 applied to and recovered from the seed (data not shown). However, there was a significant effect $(P=0.04)$ of tomato line on the amount of UW85 recovered from the seed at the 1:1 application dose. To account for the apparent host effect on the amount of UW85 that adhered to the seed, we used the amount recovered from the seed as the independent variable $(z)$ for the regression instead of the amount applied to the seed.

The three biocontrol models evaluated included the NE pathogen model in conjunction with the NE, HS, and LG biocontrol components (Table 3 ). We fit these models by assigning the values derived from the NE pathogen model (Table 5) to the pathogen parameters in the biocontrol models and estimated values for the biocontrol parameters. The NE/LG model failed to converge for all but one of the inbred lines. The NE/HS model had the best overall fit to the data based on the chi-square test but yielded very large and sometimes negative parameter values for the two tomato lines (NIJ 8 and NIJ 66) that had no response to UW85, so we also evaluated a variant of this model by bounding $I_{\max }$ between 0 and 1 (Table 6). This resulted in more reasonable parameter values but reduced the goodness-of-fit slightly. Both NE/NE biocontrol parameters, $A$ and $c$, differed among the tomato lines based on comparisons of the $95 \%$ confidence intervals. Excluding the two nonresponsive lines noted above, the NE/NE and NE/HS models ranked the lines similarly with regard to their support of biological control. NIJ 56 and NIJ 87 were the most supportive of biological control based on values for $K_{z}$ from the NE/HS model (Table 6). When we evaluated a responsive (NIJ 56) and a nonresponsive (NIJ 8) tomato line again at a single dose of UW85 and P. torulosum in two experiments, we obtained similar results. UW85 reduced mortality 49 and $46 \%$ for NIJ 56 but reduced mortality only $11 \%$ in one experiment and actually increased mortality $36 \%$ in the second experiment for NIJ 8 (data not shown).

The NE/NE and NE/HS biocontrol dose-response models both yielded good fits to the data but differed in the way that the parameters quantified host support of biological control. Lines NIJ 8 and NIJ 66 were both clearly nonresponsive to UW85 (Fig. 3). The NE/NE model fit estimates of 0 for these nonresponsive lines, whereas the NE/HS model fit negative values, which are difficult to interpret biologically (Table 6). Among the remaining four lines that were supportive of biological control, NIJ 16 was less so, as indicated by the values of either $c$ or $K_{z}$. For the four lines that did support biological control, the asymptotic correlation between parameters ranged from -0.51 to -0.71 for the NE/NE model and from 0.83 to 0.92 for the NE/HS model, indicating that over-parameterization may be more of a problem for the NE/HS model.

The size of the errors associated with parameter estimates also differed between the two models. If we calculate the ratio of the asymptotic standard error for the parameter estimate to the value of the parameter estimate, we can evaluate the degree of precision for parameter estimates. These ratios, averaged over the above four tomato lines, are $0.02,0.24,0.04$, and 0.47 for $A, c, I_{\max }$, and $K_{z}$, respectively. This would indicate that although the NE/HS model gives a slightly better fit to the data the NE/NE model provides parameter estimates with more precision. The latter attribute is important for accurate measurement of traits, which is necessary to distinguish differences among genotypes in genetic studies or breeding programs. Weighing the parameter criteria of interpretability, precision, and over-parameterization, in addition to model goodness-of-fit, suggests that NE/NE is the best model for quantifying biological control among the tomato lines in this system.
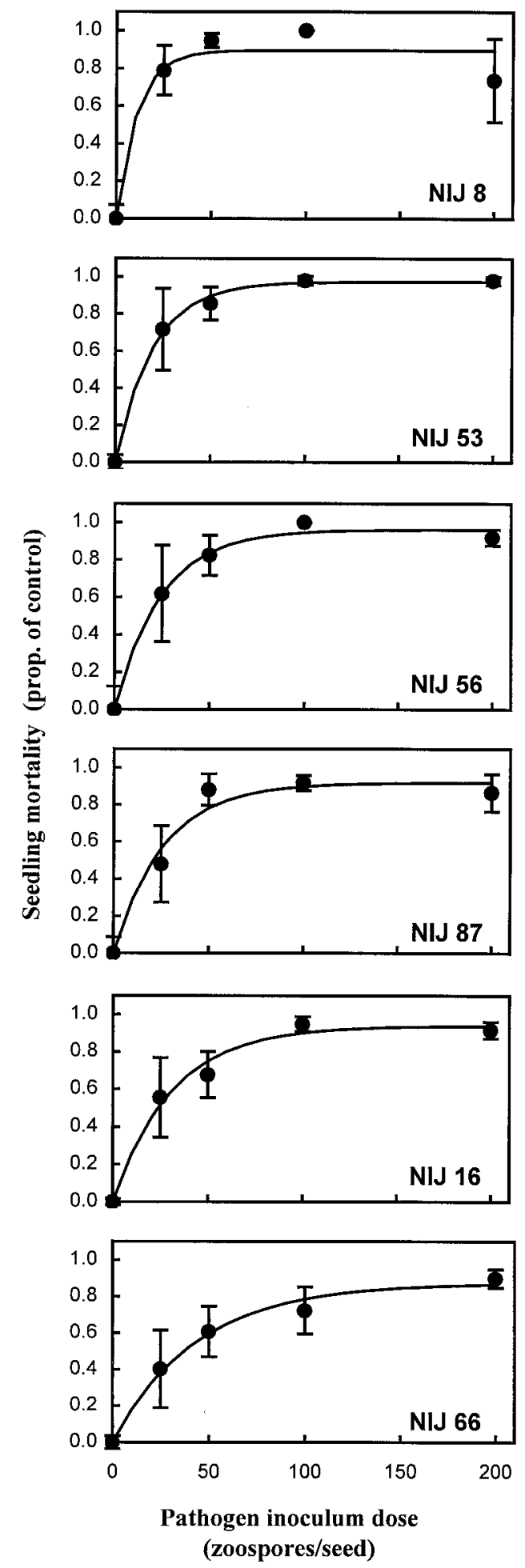

Fig. 2. Disease response of six inbred tomato lines to inoculation with Pythium torulosum. Symbols represent mean of 6 replications of 10 seeds. Lines represent values for the negative exponential pathogen model. Vertical bars represent the standard error of the mean. The parameter estimates for $L$ and $k$ are listed in Table 5. 


\section{DISCUSSION}

Extending the epidemiological principles of plant disease to include biocontrol agents will enhance our understanding of these complex systems. Two factors contribute to the challenge of measuring the host contribution to biocontrol efficacy. The first is variation in the host for resistance to the pathogen, and the second is the nonlinear response of the host to pathogen and biocontrol agent inoculum concentrations. We have taken these factors into account and tested an approach to quantify the host response to the pathogen and biocontrol agent by fitting dose-response models to seedling mortality data collected over a range of pathogen and biocontrol agent inoculum concentrations. For the models evaluated, we could estimate values for the pathogen parameters from data on host response to the pathogen, then estimate values for biocontrol parameters for a biocontrol model that was an extension of the disease model from data collected on host response to the biocontrol agent. In this way, we quantified host resistance to the pathogen first, then quantified host support of biological control.

Quantifying host responses to the biocontrol agent and pathogen. The dose-response modeling approach used in this study has several advantages for quantifying host resistance to the pathogen and support of biological control. Given a model that adequately describes the host response to the dose of the pathogen and biocontrol agent, it is possible to partition and quantify these two traits. This is particularly important for measuring the host effect on biological control when there are differences among host genotypes for resistance to the pathogen, as was the case for the six tomato lines in this study. Data obtained at relatively low pathogen doses provided the information necessary to quantify differences in pathogen resistance among tomato lines. However, the information necessary to measure host differences in support of biological control must come from disease data obtained at relatively high pathogen doses. At these high doses we could not detect differences among tomato lines for resistance to the pathogen, with the possible exception of line NIJ 66. These models provided the means to integrate information over a range of pathogen and biocontrol agent doses and accurately quantify these two traits.

Modeling dose-response relationships in biological control can provide insight into the interactions among host, pathogen, and biocontrol agent. In this study, the NE model described the host response of tomato to Pythium and assumes that pathogen prop-

TABLE 5. Parameter values and goodness-of-fit for five pathogen dose-response models evaluated for six inbred tomato lines

\begin{tabular}{|c|c|c|c|c|c|c|c|c|c|c|c|c|c|}
\hline \multirow{2}{*}{$\begin{array}{l}\text { Tomato } \\
\text { line }\end{array}$} & \multicolumn{3}{|c|}{ Negative exponential model (NE) } & \multicolumn{2}{|c|}{$\mathrm{NE}(L=1.0)$} & \multicolumn{3}{|c|}{ Hyperbolic saturation model (HS) } & \multicolumn{2}{|c|}{$\mathrm{HS}\left(Y_{\max }=1.0\right)$} & \multicolumn{3}{|c|}{ Logistic cumulative probability model } \\
\hline & $L$ & $k$ & $P^{\mathrm{a}}$ & $k$ & $P$ & $Y_{\max }$ & $K_{x}$ & $P^{\mathrm{a}}$ & $K_{x}$ & $P$ & $v$ & $\delta$ & $P$ \\
\hline NIJ 8 & $\begin{array}{c}0.90 \\
(0.23)^{\mathrm{b}}\end{array}$ & $\begin{array}{c}0.091 \\
(0.187)\end{array}$ & 0.45 & $\begin{array}{c}0.062 \\
(0.063)\end{array}$ & 0.26 & $\begin{array}{c}0.89 \\
(0.35)\end{array}$ & $\begin{array}{c}1.4 \\
(18.1)\end{array}$ & 0.38 & $\begin{array}{c}6.1 \\
(10.6)\end{array}$ & 0.29 & $\begin{array}{c}20.2 \\
(94.2)\end{array}$ & $\begin{array}{r}6.5 \\
(128.5)\end{array}$ & 0.24 \\
\hline NIJ 53 & $\begin{array}{c}0.97 \\
(0.06)\end{array}$ & $\begin{array}{c}0.051 \\
(0.013)\end{array}$ & 0.99 & $\begin{array}{c}0.047 \\
(0.009)\end{array}$ & 0.97 & $\begin{array}{c}1.06 \\
(0.08)\end{array}$ & $\begin{array}{l}11.5 \\
(4.9)\end{array}$ & 0.99 & $\begin{array}{c}8.4 \\
(3.3)\end{array}$ & 0.96 & $\begin{array}{c}20.1 \\
(13.4)\end{array}$ & $\begin{array}{c}9.7 \\
(24.1)\end{array}$ & 0.76 \\
\hline NIJ 56 & $\begin{array}{c}0.96 \\
(0.10)\end{array}$ & $\begin{array}{c}0.041 \\
(0.016)\end{array}$ & 0.96 & $\begin{array}{c}0.037 \\
(0.010)\end{array}$ & 0.92 & $\begin{array}{c}1.06 \\
(0.24)\end{array}$ & $\begin{array}{c}15.8 \\
(17.5)\end{array}$ & 0.85 & $\begin{array}{l}12.1 \\
(7.1)\end{array}$ & 0.78 & $\begin{array}{c}22.4 \\
(11.9)\end{array}$ & $\begin{array}{c}16.6 \\
(23.9)\end{array}$ & 0.62 \\
\hline NIJ 87 & $\begin{array}{c}0.92 \\
(0.20)\end{array}$ & $\begin{array}{c}0.038 \\
(0.031)\end{array}$ & 0.63 & $\begin{array}{c}0.037 \\
(0.015)\end{array}$ & 0.52 & $\begin{array}{c}1.03 \\
(0.46)\end{array}$ & $\begin{array}{c}19.0 \\
(36.9)\end{array}$ & 0.36 & $\begin{array}{c}16.8 \\
(13.7)\end{array}$ & 0.34 & $\begin{array}{c}26.7 \\
(11.8)\end{array}$ & $\begin{array}{c}17.3 \\
(23.7)\end{array}$ & 0.63 \\
\hline NIJ 16 & $\begin{array}{c}0.94 \\
(0.15)\end{array}$ & $\begin{array}{c}0.032 \\
(0.017)\end{array}$ & 0.85 & $\begin{array}{c}0.027 \\
(0.009)\end{array}$ & 0.74 & $\begin{array}{c}1.07 \\
(0.26)\end{array}$ & $\begin{array}{c}23.7 \\
(22.6)\end{array}$ & 0.86 & $\begin{array}{c}18.4 \\
(8.7)\end{array}$ & 0.79 & $\begin{array}{c}30.1 \\
(21.8)\end{array}$ & $\begin{array}{c}30.3 \\
(40.3)\end{array}$ & 0.30 \\
\hline NIJ 66 & $\begin{array}{c}0.87 \\
(0.14)\end{array}$ & $\begin{array}{c}0.023 \\
(0.011)\end{array}$ & 0.92 & $\begin{array}{c}0.016 \\
(0.005)\end{array}$ & 0.58 & $\begin{array}{c}1.06 \\
(0.15)\end{array}$ & $\begin{array}{c}40.8 \\
(17.9)\end{array}$ & 0.98 & $\begin{array}{l}34.3 \\
(6.9)\end{array}$ & 0.96 & $\begin{array}{c}49.1 \\
(41.2)\end{array}$ & $\begin{array}{c}58.6 \\
(81.4)\end{array}$ & 0.29 \\
\hline Overall $^{\mathrm{c}}$ & & & 1.000 & & 0.990 & & & 0.998 & & 0.992 & & & 0.843 \\
\hline
\end{tabular}

a Probability of the chi-square test (model = observed) for four pathogen concentrations.

$\mathrm{b}$ Adding and subtracting the value in parentheses from the parameter value constitutes a $95 \%$ confidence interval.

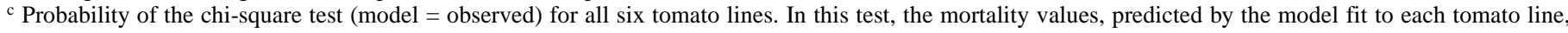
are compared with the observed values to assess how well the model predicted disease across the six tomato lines.

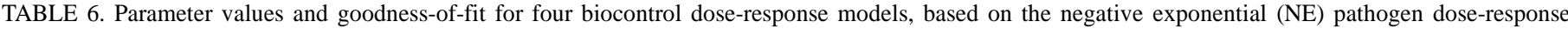
model, evaluated for six inbred tomato lines ${ }^{\mathrm{a}}$

\begin{tabular}{|c|c|c|c|c|c|c|c|c|c|c|c|c|}
\hline \multirow{2}{*}{$\begin{array}{l}\text { Tomato } \\
\text { line }\end{array}$} & \multicolumn{3}{|c|}{ NE/NE } & \multicolumn{3}{|c|}{$\mathrm{NE} / \mathrm{HS}^{\mathrm{b}}$} & \multicolumn{3}{|c|}{ NE/HS ( $I_{\max }$ bounded) } & \multicolumn{3}{|c|}{$\mathrm{LG}^{\mathrm{c}}$} \\
\hline & $A$ & $c$ & $P^{\mathrm{d}}$ & $I_{\max }$ & $K_{z}$ & $P$ & $I_{\max }$ & $K_{z}$ & $P$ & $\phi$ & $\lambda$ & $P$ \\
\hline NIJ 8 & $\begin{array}{c}0.00 \\
(0.00)^{\mathrm{f}}\end{array}$ & $\begin{array}{c}0.000 \\
(0.000)\end{array}$ & 0.83 & $\begin{array}{c}-2,875.00 \\
(30,335.99)\end{array}$ & $\begin{array}{c}822,806.0 \\
\quad(0.0)\end{array}$ & 0.83 & $\begin{array}{c}0.00 \\
(151.38)\end{array}$ & $\begin{array}{c}10.0 \\
(0.0)\end{array}$ & 0.83 & $\mathrm{FC}^{\mathrm{e}}$ & FC & \\
\hline NIJ 53 & $\begin{array}{c}0.94 \\
(0.07)\end{array}$ & $\begin{array}{c}0.028 \\
(0.011)\end{array}$ & 0.07 & $\begin{array}{c}0.98 \\
(0.08)\end{array}$ & $\begin{array}{c}13.0 \\
(19.9)\end{array}$ & 0.54 & $\begin{array}{c}0.98 \\
(0.08)\end{array}$ & $\begin{array}{c}13.0 \\
(19.9)\end{array}$ & 0.54 & FC & FC & \\
\hline NIJ 56 & $\begin{array}{c}0.86 \\
(0.07)\end{array}$ & $\begin{array}{c}0.038 \\
(0.031)\end{array}$ & 0.85 & $\begin{array}{c}0.90 \\
(0.09)\end{array}$ & $\begin{array}{c}9.5 \\
(18.5)\end{array}$ & 0.94 & $\begin{array}{c}0.90 \\
(0.09)\end{array}$ & $\begin{array}{c}9.5 \\
(18.5)\end{array}$ & 0.94 & FC & FC & \\
\hline NIJ 87 & $\begin{array}{c}0.91 \\
(0.06)\end{array}$ & $\begin{array}{c}0.030 \\
(0.018)\end{array}$ & 0.26 & $\begin{array}{c}0.95 \\
(0.13)\end{array}$ & $\begin{array}{c}9.5 \\
(20.5)\end{array}$ & 0.19 & $\begin{array}{c}0.95 \\
(0.13)\end{array}$ & $\begin{array}{c}9.5 \\
(20.5)\end{array}$ & 0.19 & FC & $\mathrm{FC}$ & \\
\hline NIJ 16 & $\begin{array}{c}0.86 \\
(0.06)\end{array}$ & $\begin{array}{c}0.012 \\
(0.006)\end{array}$ & 0.88 & $\begin{array}{c}0.98 \\
(0.17)\end{array}$ & $\begin{array}{c}56.3 \\
(58.0)\end{array}$ & 0.74 & $\begin{array}{c}0.98 \\
(0.17)\end{array}$ & $\begin{array}{c}56.3 \\
(58.0)\end{array}$ & 0.74 & FC & FC & \\
\hline NIJ 66 & $\begin{array}{c}0.00 \\
(0.00)\end{array}$ & $\begin{array}{c}0.000 \\
(0.000)\end{array}$ & 0.38 & $\begin{array}{c}0.14 \\
(0.56)\end{array}$ & $\begin{array}{c}-50.8 \\
(91.6)\end{array}$ & 0.53 & $\begin{array}{c}0.00 \\
(0.94)\end{array}$ & $\begin{array}{l}10.0 \\
(0.0)\end{array}$ & 0.38 & $\begin{array}{r}272.33 \\
\quad(4.35)\end{array}$ & $\begin{array}{l}22.02 \\
(0.00)\end{array}$ & 0.79 \\
\hline Overallg $^{2}$ & & & 0.776 & & & 0.948 & & & 0.926 & & & $\mathrm{ND}^{\mathrm{h}}$ \\
\hline
\end{tabular}

a Parameter values for $L$ and $k$, which were used to fit these models, are listed in Table 3 .

${ }^{\mathrm{b}} \mathrm{HS}=$ hyperbolic saturation model.

${ }^{\mathrm{c}} \mathrm{LG}=$ logistic cumulative probability model.

${ }^{\mathrm{d}}$ Probability of the chi-square test (model $=$ observed).

e Procedure NLIN (SAS Institute, Cary, NC) failed to converge.

f Adding and subtracting the value in parentheses from the parameter value constitutes a $95 \%$ confidence interval.

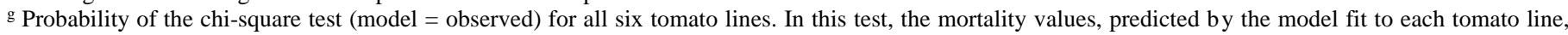
are compared with the observed values to assess how well the model predicted disease across the six tomato lines.

h Not determined. 
agules infect independently, as opposed to synergistically or antagonistically. This relationship holds true for other seedling diseases as well $(13,33)$. The asymptote and rate parameters, $L$ and $k$, respectively, from the NE model can be interpreted biologically as the maximum proportion of host individuals available to the pathogen and the efficiency of the pathogen in infecting the host, respectively. In the NE/NE biocontrol model, parameter $A$ represents the proportion of the pathogen that is affected by the biocontrol agent, whereas $c$ represents the efficiency of the biocontrol agent in suppressing the effect of the pathogen propagules. It is likely that different mechanisms of biological control, such as antibiosis, nutrient competition, or induced resistance, will result in different dose-response relationships and either affect parameter estimates of models used in this study or require different models to describe disease suppression.

We encountered some disadvantages to employing dose-response models to study interactions among host, pathogen, and biocontrol agent. To obtain precise parameter estimates, measurements at many different pathogen and biocontrol agent doses are required. In several instances in which we obtained poor fits or parameter estimates with large errors, there were insufficient data points at informative points in the dose-response curve. This experiment required more than 600 seeds for each tomato line to quantify pathogen and biocontrol parameters. Thus, the challenge is to obtain the most information on possible host responses using the available resources. Despite these limitations, we were able to distinguish quantitative differences among inbred lines for both host responses.

Another related problem is over-parameterization, which results from too few data points for the number of parameters in the model and is suggested by large values for asymptotic correlation coefficients among parameters. In the case of the pathogen doseresponse models fit to the tomato data, we were able to fix the asymptote parameter from both the NE and HS models, with only a small reduction in goodness-of-fit. These single-parameter models fit values for $k$ and $K_{x}$ with smaller confidence intervals, allowing better discrimination among the tomato lines for host response to the pathogen.

Host effect on biological control. Our objective in this study was not only to determine whether a modeling approach would be useful to quantify epidemiological parameters of disease and biological control but also to determine whether the genotype of the host influences any of these parameter values. In the tomato biocontrol assay, we found differences among tomato lines for both resistance to the pathogen and support of biological control. That these two traits are independent is suggested by results showing that the two tomato lines representing the lowest and highest levels of pathogen resistance were equally nonsupportive of biological control (Figs. 2 and 3). This implies that it may be possible to combine these two traits through breeding to improve disease suppression.

It is interesting to speculate about what specific attributes of the host, or interaction between the host and biocontrol agent, could result in superior biological control. Colonization of the spermosphere by the biocontrol agent is important for biological control of Pythium damping-off in pea (25). King and Parke $(14,15)$ found differences among four pea genotypes in biological control but not in colonization. We have preliminary evidence that there are significant differences among tomato lines for support of growth of UW85 during the first $48 \mathrm{~h}$ after planting (K. P. Smith, J. Handelsman, and R. M. Goodman, unpublished data). Further work will reveal whether these differences correspond to differences in biological control.

Antibiotics also are believed to play an important role in biological control. B. cereus UW85 produces the antibiotic zwittermicin A, which inhibits pathogen growth (28), and is correlated with disease suppression in the laboratory (30). The accumulation of this antibiotic in media is influenced by specific amino acids, iron, phosphate, and plant exudate (22). If the availability of these factors in the spermosphere is influenced by tomato genotype, then antibiotic production and disease suppression could be affected as well. In another biocontrol system, Kraus and Loper (16)
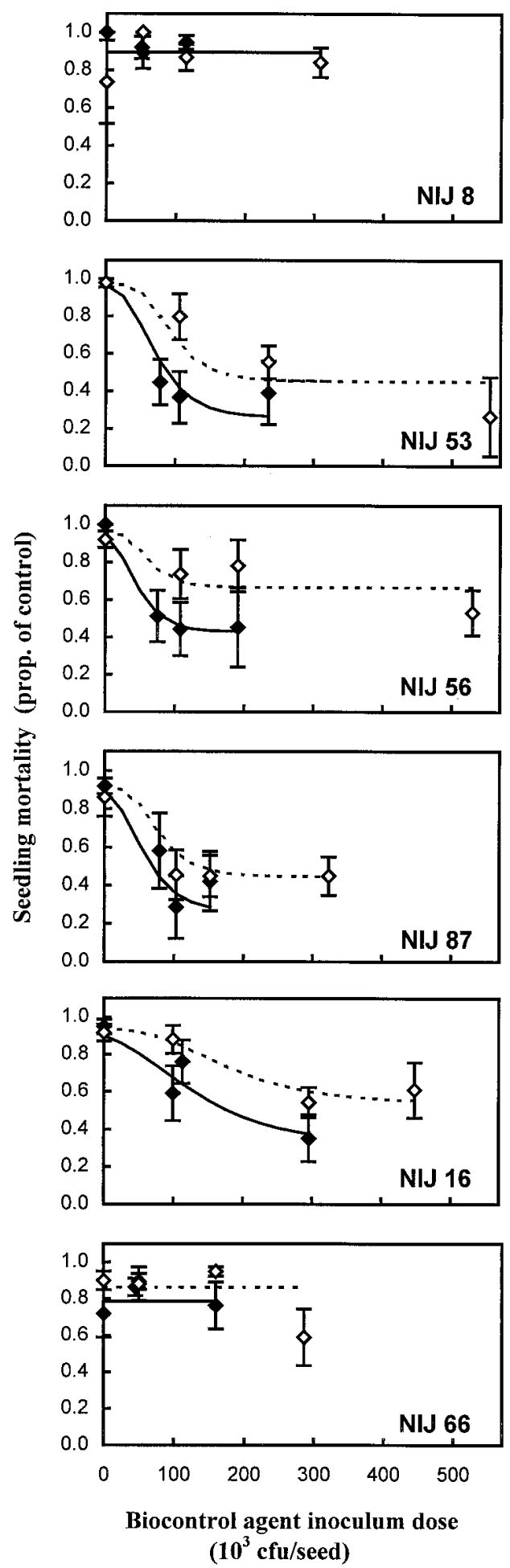

Fig. 3. Disease response of six inbred tomato lines to inoculation with Pythium torulosum and Bacillus cereus UW85. The dose of UW85 on seeds was determined empirically by sonication and dilution plating of treated seeds. The UW85 dose values are the mean of six seeds, and the standard errors were on average $23 \%$ of this value. Symbols represent the mean of 6 replications of 10 seeds. Lines represent values for the negative exponential/negative exponential biocontrol model; solid lines and solid symbols represent the values for the 100 zoospores per seed dose; open symbols and dashed lines represent the values for the 200 zoospores per seed dose. Vertical bars represent the standard error of the mean. The parameter estimates for $A$ and $c$ are listed in Table 6. 
measured transcriptional activity of the promoter controlling the expression of the antibiotic pyoluteorin, which is important for disease suppression by Pseudomonas fluorescens Pf-5, and found different patterns of activity on the spermospheres of cucumber and cotton. This suggests that the host can modify the expression of factors that contribute to the efficacy of biological control.

If the differences in biological control among the inbred lines we observed are heritable, then it should be possible to improve the ability of plants to support biological control through selection and breeding. One contribution epidemiological modeling of biological control can make to breeding is to identify selection environments that are most effective for identifying biocontrol-supportive genotypes. Screening germplasm in a breeding program is economical if done in a single environment and not over a range of pathogen and biocontrol agent doses, as was done in this study. However, information on the range of parameter values for disease resistance and biocontrol supportiveness in a plant population could facilitate identification of the environments that would be most likely to select for resistance to the pathogen from those most likely to select for support of biological control. We used the $\mathrm{NE} / \mathrm{NE}$ model to predict disease for a number of theoretical plant genotypes by plugging in parameter values that are within the ranges we have found for tomato. Using these simulated disease data, we generated a response surface defined by the doses of pathogen and biocontrol agent and identified the conditions that reveal the greatest host variation for disease resistance and biocontrol supportiveness (K. P. Smith, J. Handelsman, and R. M. Goodman, unpublished data). These preliminary simulations suggest there are specific environments that will be more productive for selection of each of these two traits.

Tomato is an attractive host for exploring a genetic basis in hosts for interaction with disease-suppressive bacteria because it is a self-pollinated diploid that exists primarily as homogeneous, homozygous lines and has been used extensively for mapping simply and quantitatively inherited traits $(7,21,26)$. Our study, thus, lays the groundwork for use of tomato to estimate heritability and map locations of major loci affecting biocontrol efficacy and to identify important host attributes associated with strong biocontrol interactions.

Future work in our laboratory is directed toward gaining an understanding of how plant genes influence plant-associated microbes, particularly those that suppress disease or in other ways benefit the plant. We are conducting selection and breeding studies to enhance the ability of the host to support biological control. The coordinated improvement of plants and beneficial microbes to manage disease may increase the effectiveness of biological control and provide a sound alternative to the use of synthetic pesticides. The use of epidemiological models to quantify biocontrol parameters and genetically define genotypes of the biocontrol agent and host should significantly enhance our understanding of biological control.

\section{AKCNOWLEDGMENTS}

Research was supported in part by grants from the University of Wisconsin, College of Agricultural and Life Sciences Research Division, the Consortium for Plant Biotechnology Research, and the McKnight Foundation. We thank J. Nienhuis, C. Grau, M. Havey, J. Coors, T. Bingham, M. Drilias, and F. Rossi for providing seed and D. Barr for identifying our Pythium isolates. We also thank C. Munson, A. Rao, and D. Johnson for technical assistance and K. Johnson and R. Nordheim for discussion of an earlier draft.

\section{LITERATURE CITED}

1. Becker, J. O., and Cook, R. J. 1988. Role of siderophores in suppression of Pythium species and production of increased-growth response of wheat by fluorescent pseudomonads. Phytopathology 78:778-782.

2. Berger, F., Hong Li, D., White, D., Frazer, R., and Leifert, C. 1996.
Effect of pathogen inoculum, antagonist density, and plant species on biological control of Phytophthora and Pythium damping-off by Bacillus subtilis Cot 1 in high-humidity fogging glasshouses. Phytopathology 86 : 428-433.

3. Bliss, F. A. 1991. Plant breeding in the 1990's. Pages 251-273 in: Symposium on Plant Breeding in the 1990's. CAB International, Wallingford, England.

4. Chanway, C. P., Nelson, L. M., and Holl, F. B. 1988. Cultivar-specific growth promotion of spring wheat (Triticum aestivum L.) by coexistent Bacillus species. Can. J. Microbiol. 34:925-929.

5. Chanway, C. P., Turkington, R., and Holl, F. B. 1988. Genotypic coadaptation in plant-growth promotion of forage species by Bacillus polymyxa. Plant Soil 106:281-284.

6. Gilbert, G. S., Handelsman, J., and Parke, J. L. 1990. Role of ammonia and calcium in lysis of zoospores of Phytophthora cactorum by Bacillus cereus strain UW85. Exp. Mycol. 14:1-8.

7. Goldman, I. L., Paran, I., and Zamir, D. 1995. Quantitative trait locus analysis of a recombinant inbred line population derived from Lycopersicon esculentum $\times$ Lycopersicon cheesmanii cross. Theor. Appl. Genet. 90:925-932.

8. Goodman, R. M., and Handelsman, J. 1993. Controlling pests and pathogens with biologicals, or why agricultural needs a program to explore inner space. Pages 187-193 in: The Governor's Conference on Agricultural Science and Technology. New York State Department of Agriculture and Markets, Albany.

9. Handelsman, J., and Stabb, E. V. 1996. Biocontrol of soilborne plant pathogens. Plant Cell 8:1855-1869.

10. Hebbar, K. P., Davey, A. G., Merrin, J., McLoughlin, T. J., and Dart, P. J. 1992. Pseudomonas cepacia, a potential suppressor of maize soil-borne diseases-Seed inoculation and maize root colonization. Soil Biol. Biochem. 24:999-1007.

11. Janisiewicz, W. 1996. Ecological diversity, niche overlap, and coexistence of antagonists used in developing mixtures for biocontrol of postharvest disease of apples. Phytopathology 86:473-479.

12. Johnson, K. B. 1994. Dose-response relationships and inundative biological control. Phytopathology 84:780-784.

13. Keinath, A. P. 1995. Relationships between inoculum density of Rhizoctonia solani, wirestem incidence and severity, and growth of cabbage. Phytopathology 85:1487-1492.

14. King, E. B., and Parke, J. L. 1993. Biocontrol of Aphanomyces root rot and Pythium damping-off by Pseudomonas cepacia AMMD on four pea cultivars. Plant Dis. 77:1185-1188.

15. King, E. B., and Parke, J. L. 1996. Population density of the biocontrol agent Burkholderia cepacia AMMDR1 on four pea cultivars. Soil Biol. Biochem. 28:307-312.

16. Kraus, J., and Loper, J. E. 1995. Characterization of a genomic region required for production of the antibiotic pyoluteorin by the biological control agent Pseudomonas fluorescens Pf-5. Appl. Environ. Microbiol. 61:849-854.

17. Kucey, R. M. N. 1988. Plant growth-altering effects of Azospirillum brasilense and Bacillus C-11-25 on two wheat cultivars. J. Appl. Bacteriol. 64:187-196.

18. Leben, S. D., Wadi, J. A., and Easton, G. D. 1987. Effects of Pseudomonas flourescens on potato plant growth and control of Verticillium dahliae. Phytopathology 77:1592-1595.

19. Leeman, M., van Pelt, J. A., den Ouden, F. M., Heinsbroek, M., Bakker, P. A. H. M., and Schippers, B. 1995. Induction of systemic resistance by Pseudomonas fluorescens in radish cultivars differing in susceptibility to Fusarium wilt, using a novel bioassay. Eur. J. Plant Pathol. 101: 655-664.

20. Liu, L., Kloepper, J. W., and Tuzun, S. 1995. Induction of systemic resistance in cucumber by plant growth-promoting rhizobacteria: Duration of protection and effect of host resistance on protection and root colonization. Phytopathology 85:1064-1068.

21. Martin, G. B., Brommonschenkel, S. H., Chunwongse, J., Frary, A., Ganal, M. W., Spivey, R., Wu, T., Earle, E. D., and Tanksley, S. D. 1993. Mapbased cloning of a protein kinase gene conferring disease resistance in tomato. Science 262:1432-1436.

22. Milner, J. L., Raffel, S. J., Lethbridge, B. J., and Handelsman, J. 1995. Culture conditions that influence accumulation of zwittermicin A by $\mathrm{Ba}$ cillus cereus UW85. Appl. Microbiol. Biotechnol. 43:685-691.

23. Montesinos, E., and Bonaterra, A. 1996. Dose-response models in biological control of plant pathogens: An empirical verification. Phytopathology 86:464-472.

24. Nelson, E. B., Chao, W. L., Norton, J. M., Nash, G. T., and Harman, G. E. 1986. Attachment of Enterobacter cloacae to hyphae of Pythium ultimum: Possible role in the biological control of Pythium preemergence damping-off. Phytopathology 76:327-335.

25. Parke, J. L. 1990. Population dynamics of Pseudomonas cepacia in the 
pea spermosphere in relation to biocontrol of Pythium. Phytopathology 80:1307-1311.

26. Paterson, A. H., Damon, S., Hewitt, J. D., Zamir, D., Rabinowitch, H. D., Lincoln, S. E., Lander, E. S., and Tanksley, S. D. 1991. Mendelian factors underlying quantitative traits in tomato: Comparison across species, generations, and environments. Genetics 127:181-197.

27. Raaijmakers, J. M., Leeman, M., van Oorscot, M. M. P., van der Sluis, I., Schippers, B., and Bakker, P. A. H. M. 1995. Dose-response relationships in biological control of Fusarium wilt of radish by Pseudomonas spp. Phytopathology 85:1075-1081.

28. Silo-Suh, L. A., Lethbridge, B., Raffel, S., He, H., Clardy, J., and Handelsman, J. 1994. Biological activities of two fungistatic antibiotics produced by Bacillus cereus UW85. Appl. Environ. Microbiol. 60:2023-2030.

29. Smith, K. P., Havey, M. J., and Handelsman, J. 1993. Suppression of cottony leak of cucumber with Bacillus cereus strain UW85. Plant Dis. 77:139-142.
30. Stabb, E. V., Jacobson, L. M., and Handelsman, J. 1994. Zwittermicin Aproducing strains of Bacillus cereus from diverse soils. Appl. Environ. Microbiol. 60:4404-4412.

31. Vakili, N. G. 1992. Biological seed treatment of corn with mycopathogenic fungi. J. Phytopathol. 134:313-323.

32. Vakili, N. G., and Bailey, T. B., Jr. 1989. Yield response of corn hybrids and inbred lines to phylloplane treatment with mycopathogenic fungi. Crop Sci. 29:183-190.

33. van Bruggen, A. H. C., Whalen, C. H., and Arneson, P. A. 1986. Effects of inoculum level of Rhizoctonia solani on emergence, plant development, and yield of dry beans. Phytopathology 76:869-873.

34. Van der Plank, J. E. 1975. Principles of Plant Infection. Academic Press, New York.

35. Van Peer, R., and Schippers, B. 1989. Plant growth responses to bacterization with selected Pseudomonas spp. strains and rhizosphere microbial development in hydroponic cultures. Can. J. Microbiol. 35:456-463. 